\title{
Optimizing resource distribution and crop productivity in hedgerow intercropping by
}

\section{manipulating tree arrangement}

\author{
Solomon Ghezehei ${ }^{\mathrm{a}, *}$, John Annandale ${ }^{\mathbf{b}}$, Colin Everson ${ }^{\mathrm{b}}$ \\ ${ }^{a}$ Department of Forestry and Environmental Resources, North Carolina State University, Raleigh 27695, USA \\ ${ }^{b}$ Department of Plant Production and Soil Science, University of Pretoria, Pretoria 0002, South Africa
}

\begin{abstract}
The potential of tree arrangement in optimizing radiation and soil water distribution and crop yield of hedgerow intercropping systems was investigated using a Jatropha curcas-Pennisetum clandestinum (kikuyu) system (Ukulinga, South Africa). Treatments (1110 t ha ${ }^{-1}$ ) of Jatropha-only (JO), single-row Jatropha and kikuyu (SR), and double-row Jatropha and kikuyu (DR) were used. Treatments had asymmetrical radiation distribution across tree-crop (T-C) interfaces and different radiation interception by trees (JO: $27 \%$, SR: $11 \%$, DR: $8 \%$ ). Soil water varied among treatments and was asymmetrically distributed showing no consistent trend towards trees. Evapotranspiration was higher $(p<0.05)$ in SR than DR $(13-65 \%)$ and JO $(16-37 \%)$ for most part of the season. Estimated fine tree roots distribution was symmetrical in DR but not JO and SR. Total roots in SR were concentrated in the top $0.2 \mathrm{~m}(91 \%)$ and beneath tree row $(30 \%)$, and varied inconsistently with distance from trees. Grass yields increased farther from tree rows and were higher in SR $\left(8.7 \mathrm{t} \mathrm{ha}^{-1}\right.$ in 2006-2007; $4.3 \mathrm{t} \mathrm{ha}^{-1}$ in 2007-2008) than DR (by <9 \%). Radiation use efficiency of kikuyu $\left(0.14-0.44 \mathrm{~g} \mathrm{MJ}^{-1}\right)$ also increased with distance from trees but irradiance correlated with grass yields poorly $\left(\mathrm{R}^{2}<0.32\right)$ despite high rainfall and no nutrient limitation. Considering total productivity and evapotranspiration, DR was better tree arrangement than SR. Water availability dictated $\mathrm{T}-\mathrm{C}$ interactions and intercrop yield more than radiation. It was possible to optimize radiation and water distribution and intercrop growth by manipulating tree arrangement without changing density.
\end{abstract}

\section{Keywords}

Efficient agroforestry design Growth Radiation use efficiency Silvopasture Tree-crop interactions

\section{$1 \quad$ INTRODUCTION}

Production of food crops and pastures in South Africa faces deterioration and limited arability of land and relatively low and erratic rainfall. Moreover, yields and food security are compromised by low agricultural production technologies practices and low inputs in resource-poor communities. One of such regions is the Coast Hinterland Thornveld region, which is classified as Bioresource Group 17 (Camp, 1997). This warm temperate region with annual rainfall (according to the Köppen classification) has an area of 113367 ha and is characterized by severely degraded natural resources due to continuous burning to enhance fresh growth and selective overgrazing, poor water supply, frequent droughts and only $33 \%$ arable land. Vegetation in the area is wooded grasslands, woodlands and bushed grasslands dominated by secondary Acacia species and Aristida junciformis grass, which is an inedible by livestock (Everson et al. 2012). The potential exists for agroforestry to 
be implemented a resource-efficient production system to rehabilitate the land, produce fodder to reduce pressure on the natural grasslands, and generate additional income by employing species that are tolerant to poor soils and not excessive water users.

To ascertain sustainability of agroforestry systems, understanding factors and interactions involved is essential (Berlyn and Cho 2000; Ong et al 2000). Tree-crop (T-C) interfaces can be regulated effectively (Huxley, 1999), and interspecies competition can be minimized by employing efficient design (Garrett and McGraw 2000) and selecting compatible species (Ong et al. 2002, 2014; Bayala and Wallace 2015; Black et al. 2015; Ong and Kho 2015). Due to the importance of understanding system functioning and implementing and managing efficiently designed systems, our objectives were to understand the extent of T-C interactions in hedgerow intercropping systems (HI) by examining distribution of solar radiation, soil water and root, intercrop growth, and possibility of manipulating distribution of radiation and water and intercrop growth by optimizing tree arrangement without changing tree density. Three hypotheses were formulated namely: pasture production can be linearly related to radiation if other resources are non-limiting; in a well-fertilized and rain-fed HI in semi-arid areas, water availability is more critical than radiation, and distribution of radiation and soil water and intercrop growth can be optimized by manipulating tree arrangement without changing density.

\section{MATERIALS AND METHODS}

\subsection{Site description}

The current study was conducted in a rain-fed silvopastoral system at the Ukulinga Research Farm, Pietermaritzburg South Africa (30 $24^{\prime}$ S, $\left.29^{\circ} 24^{\prime} E\right)$. Ukulinga has an altitude of 781 m.a.s.l., mean rainfall of 680 $\mathrm{mm} \mathrm{yr}^{-1}$, and warm to hot summers and mild winters. The site was flat land with a $0.6 \mathrm{~m}$ deep profile underlain by bedrock, and loam to clay loam soil with generally increasing clay content with depth.

Treatments were arranged in a randomized block design with three replicates, and included Jatropha (Jatropha curcas L.) with no intercrops (JO: $3 \mathrm{~m}$ x $3 \mathrm{~m}$ ), single Jatropha hedgerow with intercropped kikuyu (Pennisetum clandestinum) (SR: $5 \mathrm{~m} \times 2 \mathrm{~m}$ ) and double Jatropha hedgerows (2.5 m apart and $2 \mathrm{~m}$ intra-row spacing) with 6 m-wide kikuyu intercropping (DR). Fig. 1 shows layout of the treatments. Plots were $50 \mathrm{~m}$ by $25 \mathrm{~m}$ with a tree density of $1100 \mathrm{ha}^{-1}$ and a row orientation of $\mathrm{N} 17^{\circ} \mathrm{W}$ to $\mathrm{S} 17^{\circ} \mathrm{E}$. The motivation for the Jatropha-Kikuyu system was its potential to improve livelihood of small-scale farmers as a source of pasture and income (through the sale of Jatropha nuts). Kikuyu has a high capacity as a grazing pasture even under dryland conditions, and Jatropha was selected due to its bio-diesel rich nuts, tolerance to drought and low soil fertility and inedibility by the animal components of silvopastoral systems. 


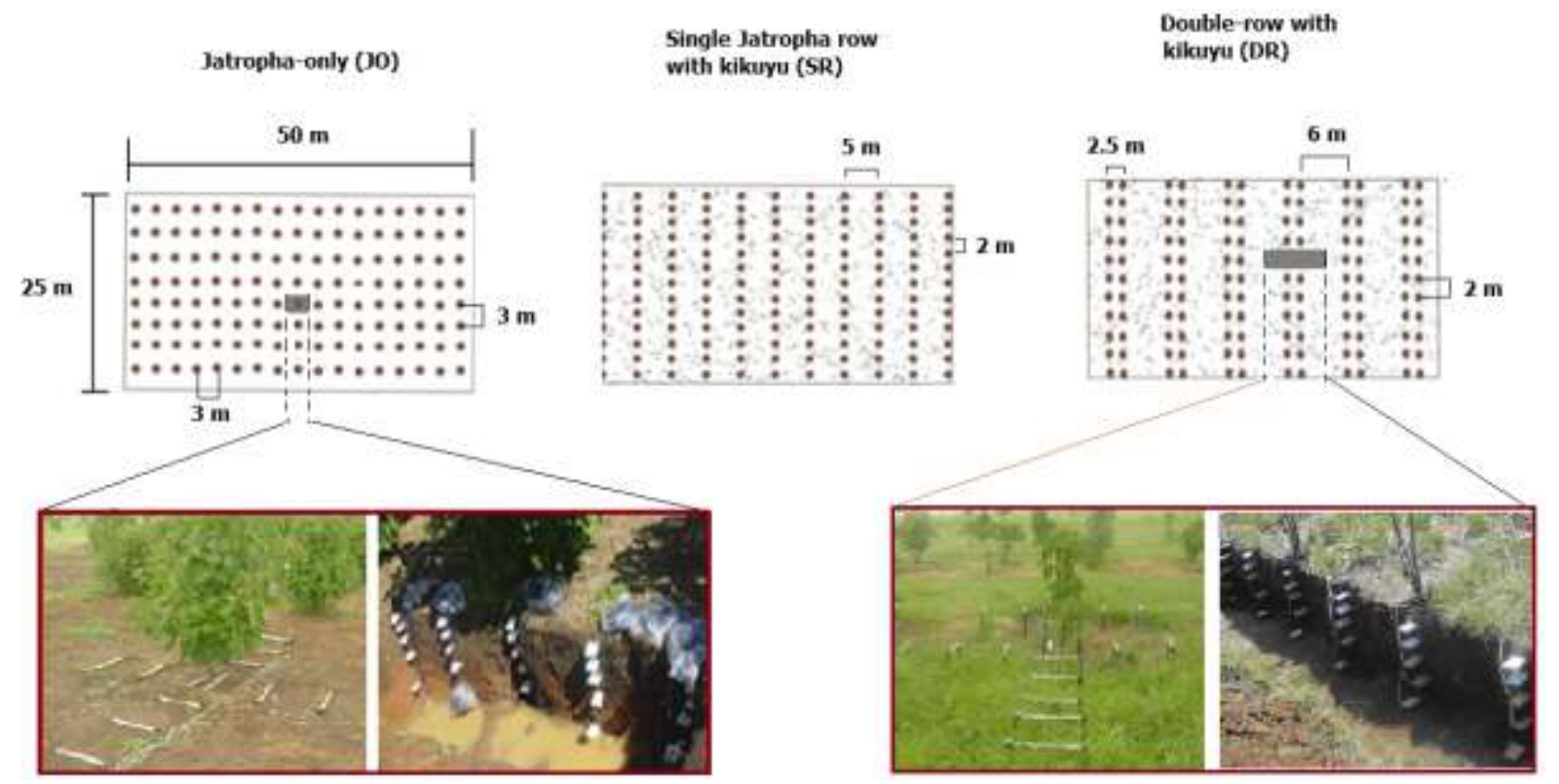

Fig. 1 Experimental layout of the Jatropha-only (JO), single Jatropha row with intercropped kikuyu (SR) and double Jatropha hedgerows with intercropped Kikuyu (DR) treatments at Ukulinga, South Africa. The inserted pictures demonstrate instrumentation of solarimeters and TDR probes

\subsection{Data collection and analyses}

An automatic weather station was used to monitor weather variables including incident solar radiation (using LI 200x pyranometer) and rainfall (with Rimco R/TBR tipping bucket). CR 10x data logger (Campbell Scientific Inc.) was used to monitor and record the measurements. Calibrated Delta-T tube solarimeters (Delta-T Devices Ltd, Cambridge, England) were used to measure hourly radiation distribution across tree hedgerows extending between halfway of adjacent intercrop zones in JO, SR and DR. The solarimeters were placed at the soil surface in JO and below tree crowns and above the grass in SR and DR on the south-western (SW) and north-eastern (NE) sides at distances of $0 \mathrm{~m}$ (below tree row), $0.75 \mathrm{~m}$ and $1.5 \mathrm{~m}$ in $\mathrm{JO}, 0 \mathrm{~m}, 0.83 \mathrm{~m}, 1.63 \mathrm{~m}$ and $2.5 \mathrm{~m}$ in $\mathrm{SR}$, and $0 \mathrm{~m}$ (between tree rows), $1 \mathrm{~m}$ (below tree rows), $2 \mathrm{~m}, 3 \mathrm{~m}$ and $4 \mathrm{~m}$ in DR. Radiation intercepted by trees of a treatment was calculated as the difference of incident radiation measured at the weather station and areaaveraged irradiance based on measurements at the selected positions of the treatment.

To monitor soil water dynamics, three-rod CS605 time domain reflectometry (TDR) probes (Campbell Scientific Inc.) were installed at $0.05 \mathrm{~m}, 0.15 \mathrm{~m}, 0.25 \mathrm{~m}, 0.40 \mathrm{~m}$ and $0.60 \mathrm{~m}$ depths and using the same orientations as the radiation study. Prior to the installation, waveforms of the TDR probes were tested using PCTDR software (TDR Graphing PC Software, Version 2.07; Copyright @) 1997, 2001, Campbell Scientific, Inc.) and the probes were calibrated by gravimetric method using a composite soil sample from the site. Backfilling of the trenches dug for TDR installation was done in $0.1 \mathrm{~m}$-thick layers followed by manual 
ramming, and the profile was topped-up with kikuyu transplant with its undisturbed soil from the study site. Soil water deficit (SWD) was calculated as field capacity minus actual water content where field capacity was determined in the laboratory using core samples collected from the abovementioned depths. Runoff was assumed to occur when profile water content exceeded field capacity, and calculated as the difference of the two water contents. Assuming drainage to be negligible due to underlying bed-rock, evapotranspiration (ET, mm) was determined the difference of rainfall $(\mathrm{mm})$ and change in soil water content $(\mathrm{mm})$

Grass yield above a stubble height of $50 \mathrm{~mm}$ was monitored periodically using a $0.5 \mathrm{~m}$ x $0.5 \mathrm{~m}$ quadrant on NE and $\mathrm{SW}$ at $0.83 \mathrm{~m}, 1.67 \mathrm{~m}$ and $2.5 \mathrm{~m}$ from the tree hedgerow in SR and $2 \mathrm{~m}, 3 \mathrm{~m}$ and $4 \mathrm{~m}$ positions in DR. ANOVA (SAS software, Version 9.01 of the SAS System for Windows; Copyright @ 2002 by SAS Institute Inc.) was performed on the harvests to determine if positions with respect to tree rows affected kikuyu productivity. The following statistical model was applied:

$$
y_{i j}=\mu+\alpha_{i}+\beta_{j}+\varepsilon_{i j}
$$

Where: $\mu$ is the overall mean of the experiment, $\alpha_{i}$ and $\beta_{j}$ denote random treatment and block effects respectively and $\varepsilon_{i j}$ signifies random error

Radiation use efficiency (RUE) of the pasture was also determined as a ratio of yield to cumulative irradiance at the above-mentioned positions in SR and DR. RUE was quantified as an indicator of the quality of radiation, and in conjunction with soil water, to examine which of the resources was more limiting to pasture growth. For instance, high irradiance at a certain position where the pasture yield is low may indicate limited water availability.

Leaf area index (LAI) of the trees was monitored using LAI-2000 Plant Canopy Analyzer (Li-Cor Biosciences, Li-Cor, Inc.). Monthly relative growth rates (RGRs) of basal tree diameter in JO, SR and DR were determined for the period of November 2007 to July 2008 as:

$$
\operatorname{RGR}(\%)=100\left(\left(\mathrm{D}_{2}-\mathrm{D}_{1}\right) /\left(\mathrm{t}_{1}-\mathrm{t}_{2}\right)\right) / \mathrm{D}_{1}
$$

Where $D_{1}$ and $D_{2}$ represent stem diameters at times $t_{1}$ and $t_{2}$ respectively.

Correlations between tree RGR and SWD were used to infer fine tree root distribution and isolate the role of trees in T-C competition for water, an approach similar to that of Balandier et al. (2008). Distribution of total (tree and grass) root was examined in SR by digging a trench across a tree hedgerow and collecting core samples from depth increments of $0-0.2 \mathrm{~m}, 0.2-0.4 \mathrm{~m}$ and $0.4-0.6 \mathrm{~m}$ and $0 \mathrm{~m}, 1.25 \mathrm{~m}$ and $2.5 \mathrm{~m}$ from the 
hedgerow on SW and NE. Due to woody roots in some samples, sample volumes were determined by displacement method, i.e., volume of a core sample was equal to the volume of water it displaced when immersed in the water. Roots were isolated from soil by dispersing samples in water and sieving the mixture using $0.5 \mathrm{~mm}$ wire mesh. Root biomass density $\left(\mathrm{kg} \mathrm{m}^{-3}\right)$ was then calculated as the ratio of oven-dried root biomass to volume of the sample.

\section{RESULTS}

During the study years (2006-2008), annual rainfall range was $171 \mathrm{~mm}$ (2008) to $818 \mathrm{~mm}$ (2006), with winter rainfall accounting for up to $30 \%$ of the total annual rainfall. Mean annual temperature range was between 17.8 ${ }^{\circ} \mathrm{C}(2006)$ and $19.4{ }^{\circ} \mathrm{C}(2008)$.
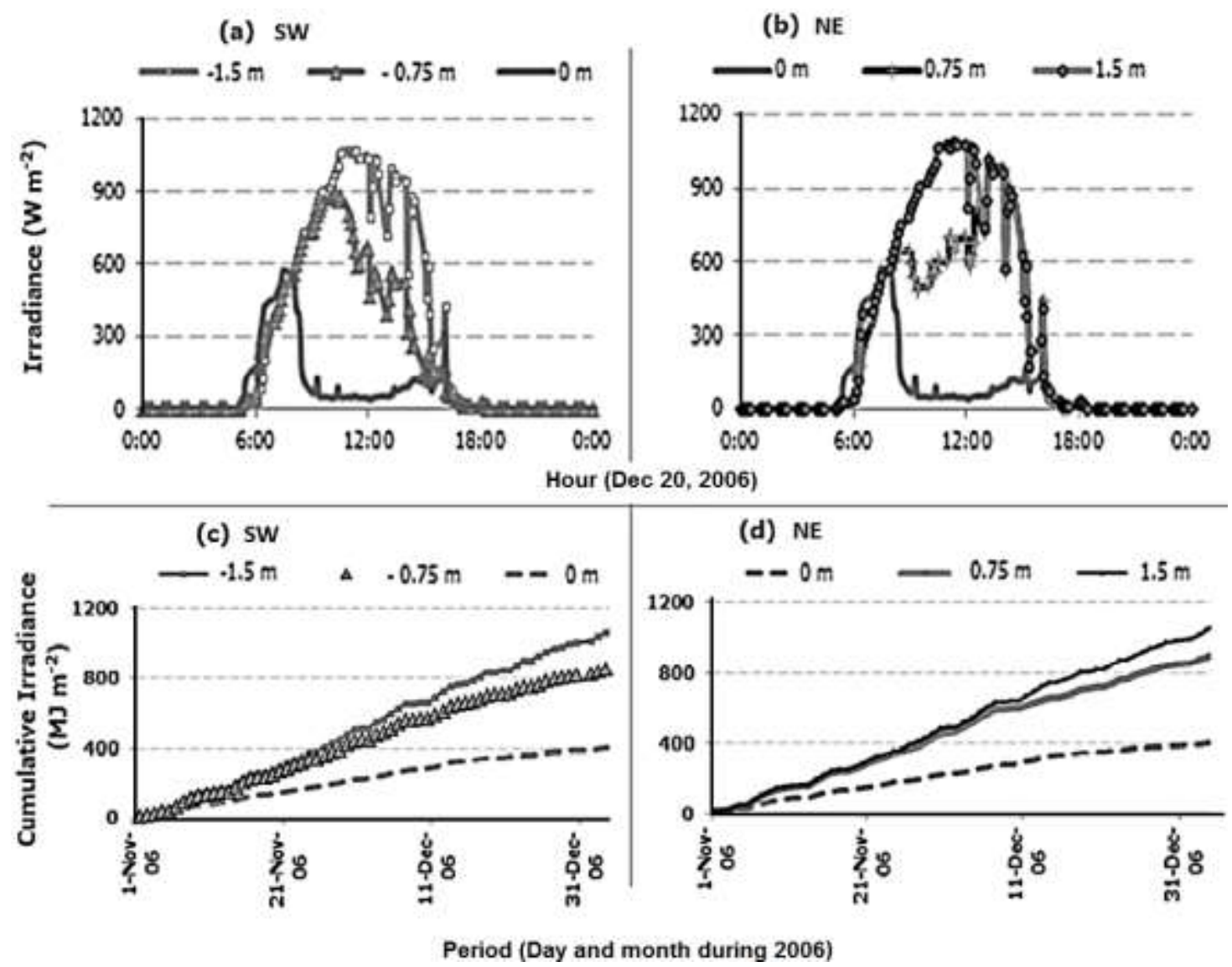
(a) $\mathrm{sw}$

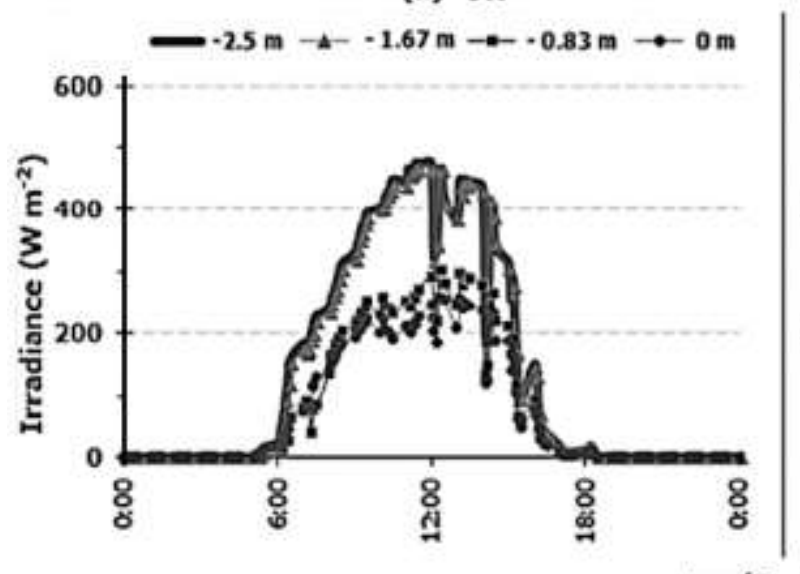

(b) NE

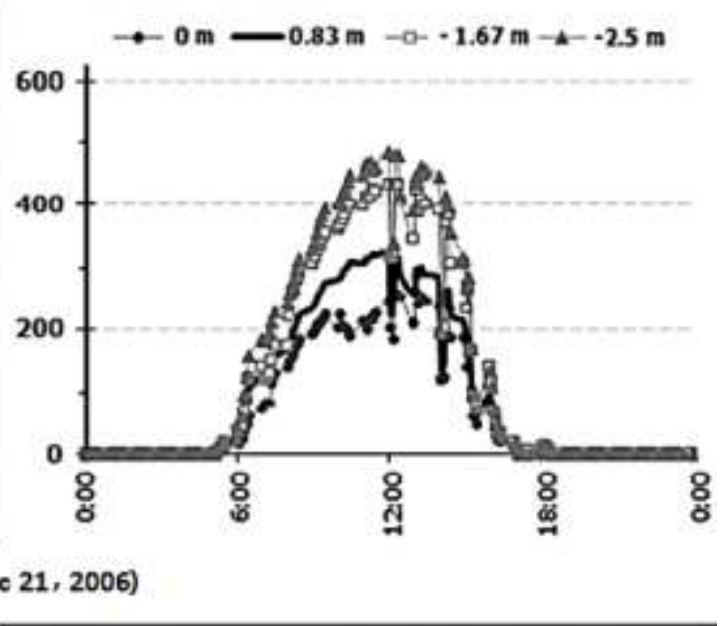

(c) SW

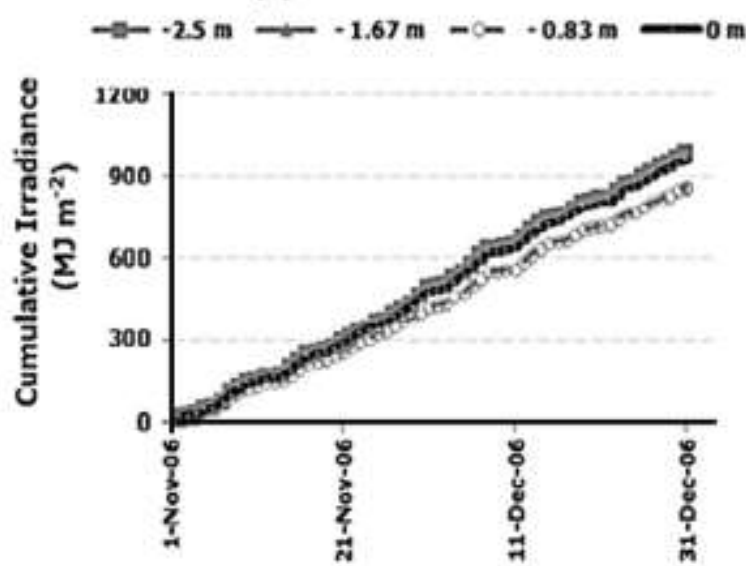

(d) NE

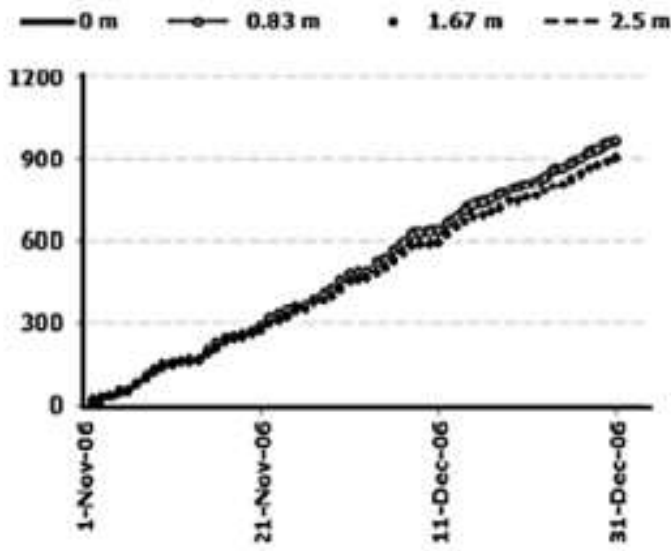

Period (Day, Month during 2006)

Fig. 3

Diurnal (a, b) and cumulative irradiance during November and December 2006 (c, d) at different positions across a tree hedgerow (0 m) on southwestern side (SW, negative

distances) and northeastern side (NE, positive distances) in the single-row with kikuyu treatment (SR) at Ukulinga, South Africa

\subsection{Radiation distribution}

In JO, cumulative irradiance on SW and NE was comparable, even at $0.75 \mathrm{~m}$ where diurnal irradiance differed between SW and NE (Fig. 2a, b). Radiation transmissions increased with distance from trees (> 95\% at $1.5 \mathrm{~m},>$ $82 \%$ at $0.75 \mathrm{~m},>50 \%$ beneath tree row). The growing difference in cumulative irradiance between $0.75 \mathrm{~m}$ and $1.5 \mathrm{~m}$ (Fig. 2c, d) was associated with increasing tree LAI (Fig. 5). In SR, irradiance was asymmetrically distributed across the hedgerow, mainly differing at $1.67 \mathrm{~m}$ (Fig. 3a, b). Variations in transmitted radiation among distances were less steep in SR than JO due to higher LAI and bigger tree canopy in the latter. In DR, irradiance was less on NE than SW (Fig. 4a, c) and the highest beneath the tree rows (Fig. 4b). Radiation partitioning differed among treatments. From November 01 to December 16 2006, tree in JO intercepted 223 MJ 
(27.1\% of irradiance) and $600 \mathrm{MJ}$ of radiation was transmitted to the soil. In SR, trees intercepted $92 \mathrm{MJ}$ (11.2\% of irradiance) and the amount of transmitted radiation was $731 \mathrm{MJ}$. Despite similar LAI to SR trees, DR trees intercepted only $8 \%$ (66 MJ of irradiance) and transmitted radiation amount was $757 \mathrm{MJ}$.

(a) Sw

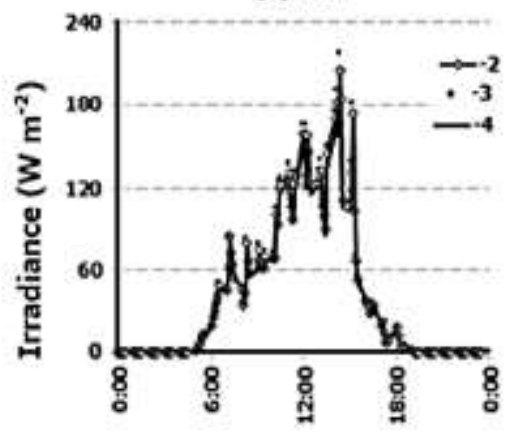

(b)

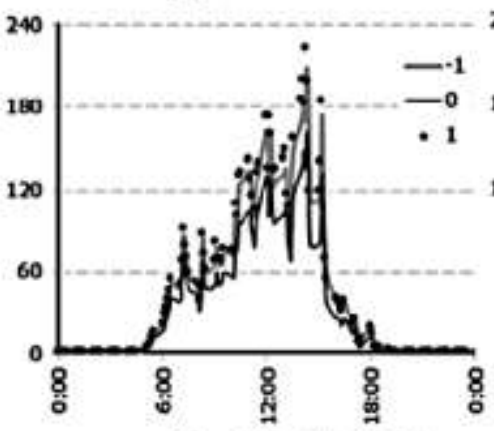

Hour (Dec 19, 2006)

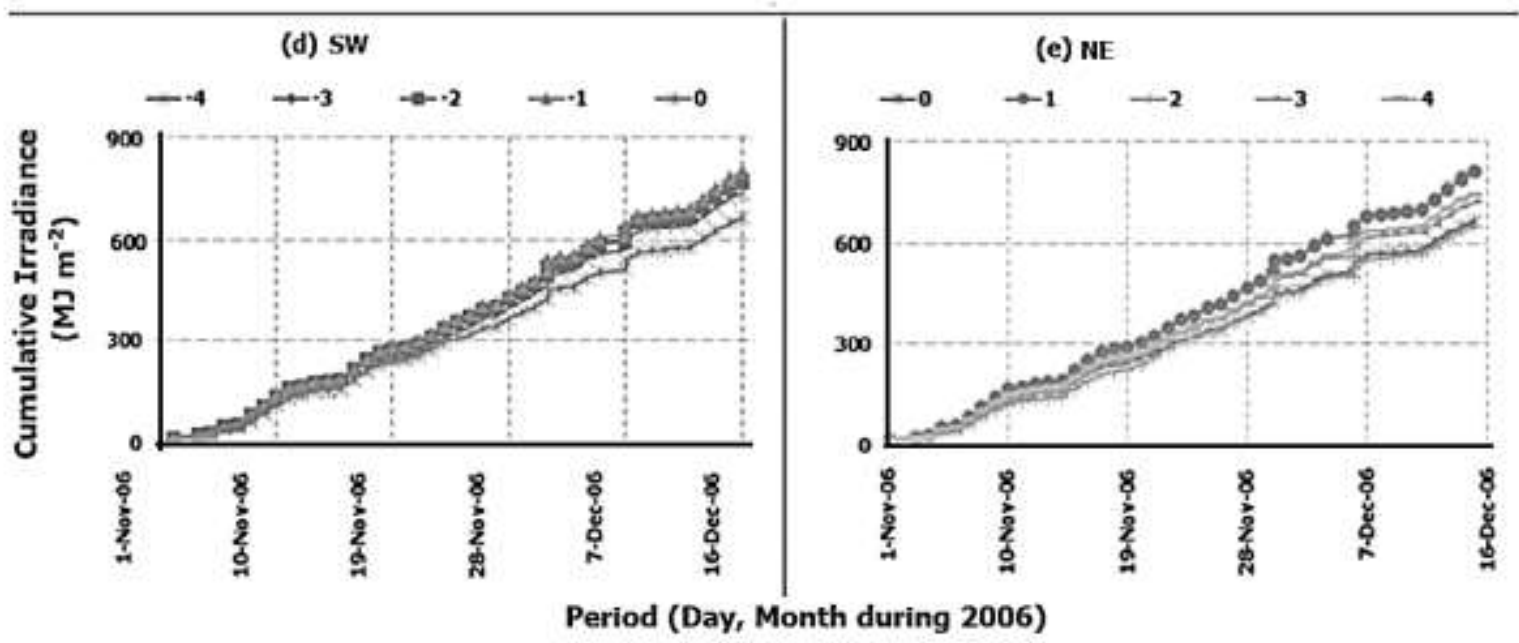

Fig. 4 Diurnal (a, b, c) and cumulative irradiance during November and December 2006 (d, e) at different positions across tree hedgerows on southwestern side (SW, negative distances) and northeastern side (NE, positive distances) in the double-row treatment (DR) at Ukulinga, South Africa. Positions represent distances from halfway between the hedgerows $(0 \mathrm{~m})$ 


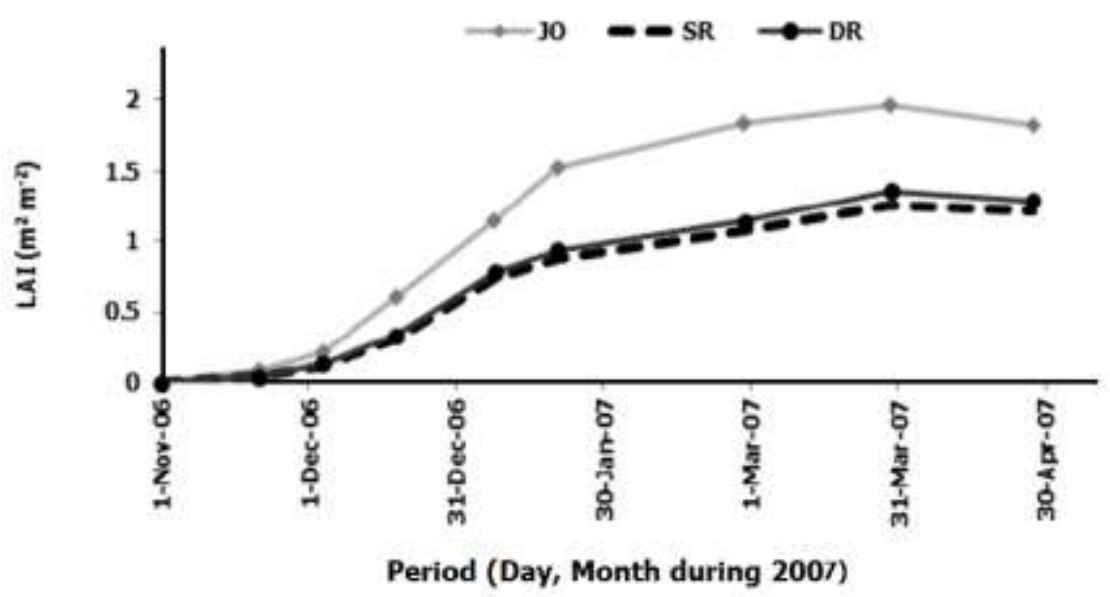

Fig. 5

LAI ( $\mathrm{m} 2 \mathrm{~m}$-2) of Jatropha in the Jatropha-only (JO), single-row with kikuyu (SR) and double-row (DR) treatments at Ukulinga, South Africa during the $2006-2007$ season

\subsection{Water balance and dynamics}

Soil water generally increased with depth due to increasing clay content and reduced evaporation. In JO, there were differences in soil water at $0.05 \mathrm{~m}$ depth between corresponding positions of $0.75 \mathrm{~m}$ and $1.5 \mathrm{~m}$ on NE and SW (Fig. 6) despite similar irradiance. Wet-period water content below trees $(0 \mathrm{~m})$ was the highest due to stem flow and reduced soil evaporation (shading). SW had lower soil water than NE and the difference increased with distance from the tree row. The highest drop in water content $(159 \mathrm{~mm})$ between wet and dry periods was at 1.5 m SW (other distances, 116 to $121 \mathrm{~mm}$ ), which was also where irradiance was the highest (based on 2006-07). ET was the lowest at $0.75 \mathrm{~m} \mathrm{SW}$ for most part of the study period and the differences with other positions were higher during dry periods (October/November 2007 and after February 2008).

RGR-SWD correlation at profile level was high $\left(\mathrm{R}^{2} \approx 0.91\right)$ and correlations were stronger closer to the tree rows. The weakest RGR-SWD correlation $\left(\mathrm{R}^{2}=0.47\right.$ at $\left.1.5 \mathrm{~m} \mathrm{SW}\right)$ occurred where soil water at $0.05 \mathrm{~m}$ depth was the lowest (Fig. 6) and the highest ET was maintained, indicating high evaporation and low transpiration proportions. The highest correlation $\left(\mathrm{R}^{2}>0.96\right)$ at $0.75 \mathrm{~m} \mathrm{NE}$ and corresponding low dry-period water content indicated high fine tree root concentration. RGR-SWD correlation was the highest within $0.2-0.4 \mathrm{~m}$ of the soil depth $\left(\mathrm{R}^{2} \approx 0.95\right)$ followed by $0.4-0.6 \mathrm{~m}$ depth $\left(\mathrm{R}^{2} \approx 0.73\right)$. It can be inferred that fine root distribution of trees in JO was skewed towards NE and mainly concentrated within $0.2-0.6 \mathrm{~m}$ depth and closer to the trees.

In SR, wet-period soil water was generally higher on NE than SW and the lowest water content was beneath the trees. During dry periods, soil water generally decreased with distance from the hedgerow. The $0.83 \mathrm{SW}$ and $1.67 \mathrm{~m} \mathrm{NE}$ maintained high soil water, and irradiance at these positions was lower than other distances. The highest water content difference between wet and dry periods $(175 \mathrm{~mm}$ ) at $2.5 \mathrm{~m} \mathrm{NE}$ (others 127 to $151 \mathrm{~mm}$ ) 


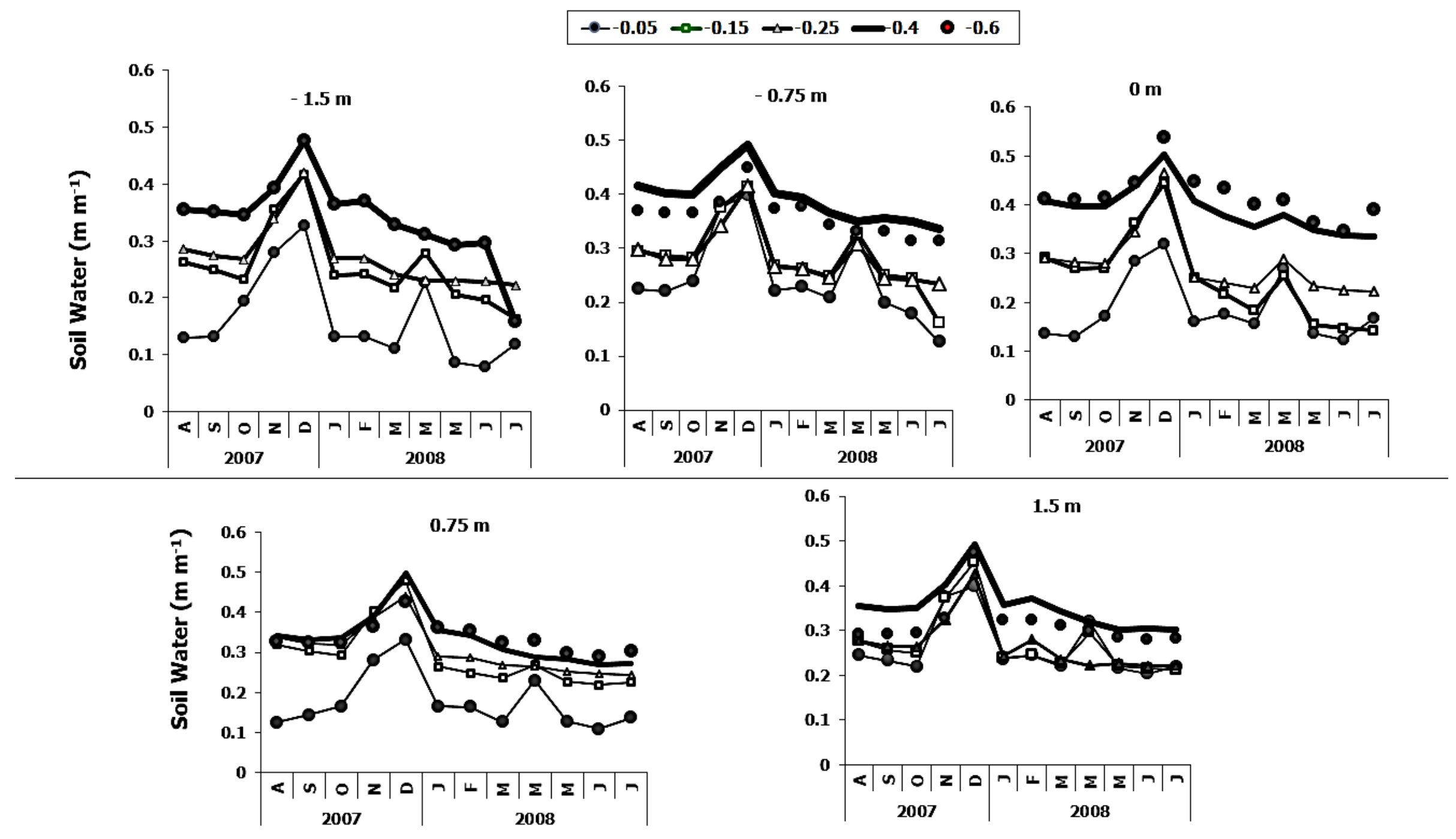

Fig. 6 Soil water fluctuations with depth at selected positions across a tree hedgerow ( $0 \mathrm{~m}$ ) on southwestern (negative distance) and northeastern (positive distance) sides in the Jatropha-only treatment (JO) at Ukulinga, South Africa between August 2007 and July 2008 
coincided with high irradiance and the highest dry-period ET at the position. Profile RGR-SWD correlation was strong $\left(\mathrm{R}^{2}=0.78\right)$, and the $0.83 \mathrm{~m}$ positions on $\mathrm{SW}$ and NE had the highest RGR-SWD correlations $(>0.9)$ and the lowest grass yield (Fig. 11) implying low evaporation and kikuyu water use at these position. The highest grass yield $\left(7.03 \mathrm{t} \mathrm{ha}^{-1}\right)$ and strong RGR-SWD correlation at $2.5 \mathrm{~m} \mathrm{NE}$ suggested transpiration was the major component of the high ET and the highest water content difference between wet and dry periods $(159.8 \mathrm{~mm})$. The poorest RGR-SWD correlations at $1.67 \mathrm{~m} \mathrm{SW}$ and $0 \mathrm{~m}\left(\mathrm{R}^{2}<0.57\right)$ corresponded to the lowest water content differences between wet and dry periods $(124 \mathrm{~mm})$ in the former, and coincided with low water content within $0.05 \mathrm{~m}$ depth in the latter (Fig. 7) where soil cover was absent. RGR-SWD correlation within $0-0.2 \mathrm{~m}$ of the soil was stronger in $\mathrm{SR}\left(\mathrm{R}^{2} \approx 0.58\right)$ than $\mathrm{JO}\left(\mathrm{R}^{2} \approx 0.28\right)$, which could be due to $\mathrm{T}-\mathrm{C}$ competition in $\mathrm{SR}$ forcing tree roots to explore the layer to a greater extent. Neither distance nor depth affected strength of RGRSWD correlations consistently. It can be inferred that fine trees roots were more concentrated within $0.2-0.6$ depth and skewed towards NE. Distribution of total root in SR was asymmetrical (Fig. 8a-d), with higher root density within $0-0.2 \mathrm{~m}$ of the soil on SW (Fig. 8a), which had lower root density than NE within $0.2-0.6 \mathrm{~m}$ (Fig. 8b, c). The highest root biomass $(91.4 \%$ ) was within the $0-0.2 \mathrm{~m}$ depth and below the tree (Fig. 8d, e) where RGR-SWD correlations were the lowest $\left(\mathrm{R}^{2}=0.57\right)$. This was due to the high proportion of woody roots at this positions. Within $0.2-0.6$ depth, root density was generally higher on NE, which was generally in agreement with our inferences based on RGR-SWD correlations.

Soil water in DR generally increased with depth (Fig. 9), and wet-period water contents varied on SW and NE inconsistently whereas dry-period water content was higher on SW. Water content beneath NE tree row was lower than the SW tree row during wet and dry periods, and ET was generally higher in NE during extended dry periods. All RGR-SWD correlations in DR were strong $\left(\mathrm{R}^{2}>0.91\right)$, suggesting that distribution of fine tree roots in the soil profile was essentially symmetrical.

ET differences among treatments were significant $(p<0.05)$ (Fig. 10, Table 1). From August to November 2007, ET in SR was higher than in DR (by 13-65\%) and JO (by 16-37\%). ET in DR was lower than in JO and SR by $47 \%$ in December. During January and February 2008, JO had more ET than SR and DR by $6 \%$ and $56 \%$ respectively. ET in SR during March to July 2008 was higher than in JO (9-15\%) and DR (25-57\%). The ET gap among treatments narrowed after extended dry periods (June and July 2007 and May 2008 onwards). During winter and extended dry periods, both kikuyu and Jatropha were largely dormant and evaporation was comparable among treatments. From November 2007 to May 2008, tree growth and growth or presence of grass varied among treatments resulting in increasing differences in ET. Differences in plant growth among 


\section{$\neg-0.05-\triangle-0.15-\square-0.25 \square-0.4 \bullet-0.6$}
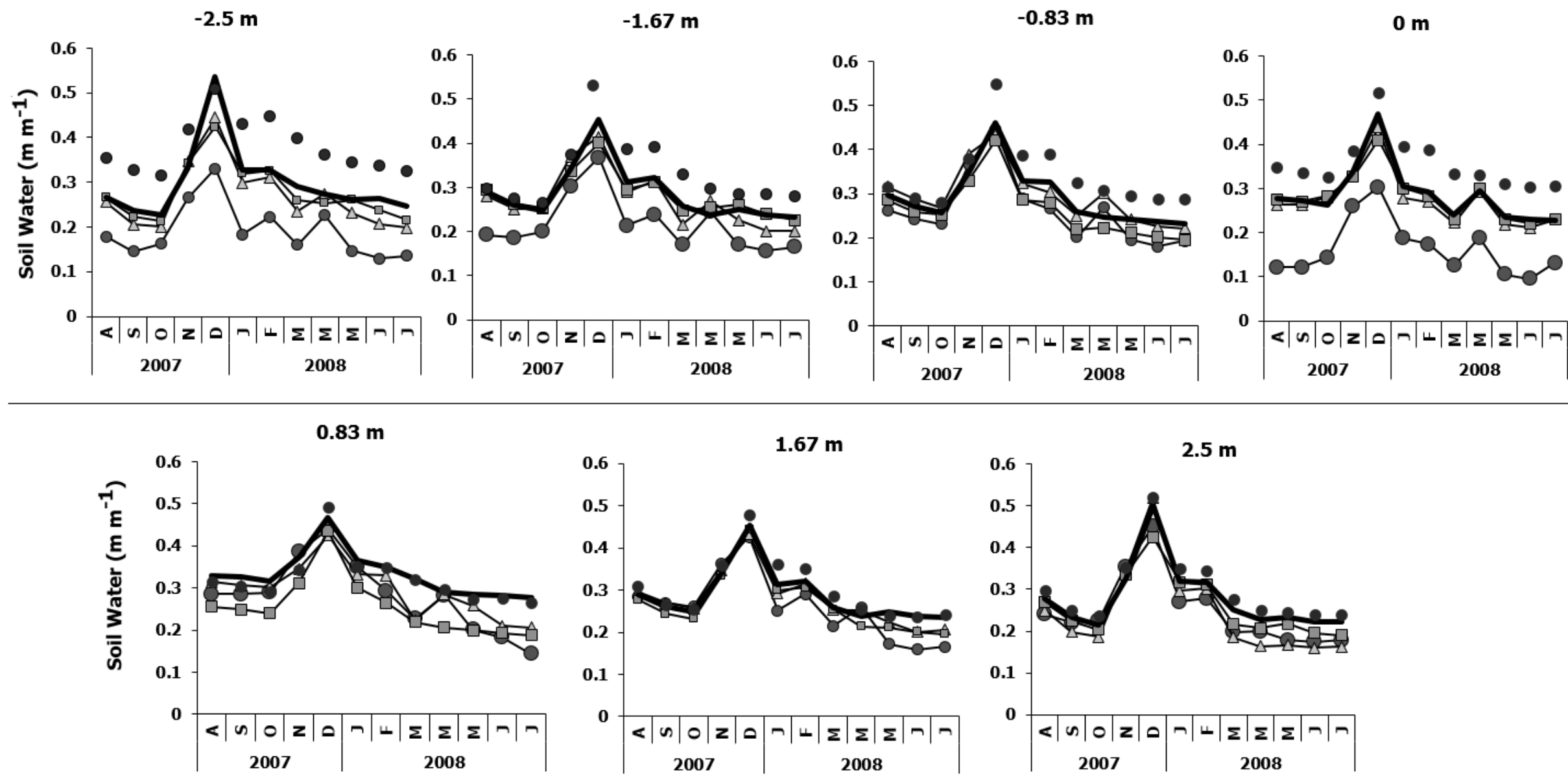


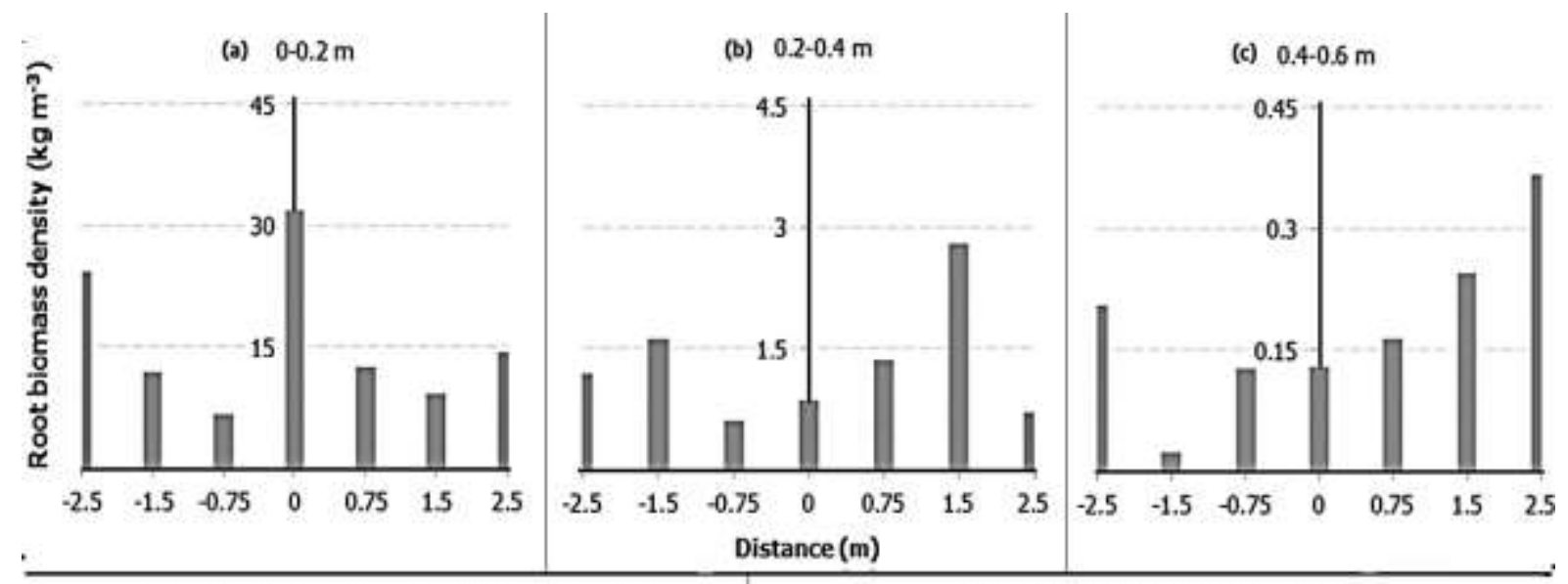

(d) Root distribution with distance from tree

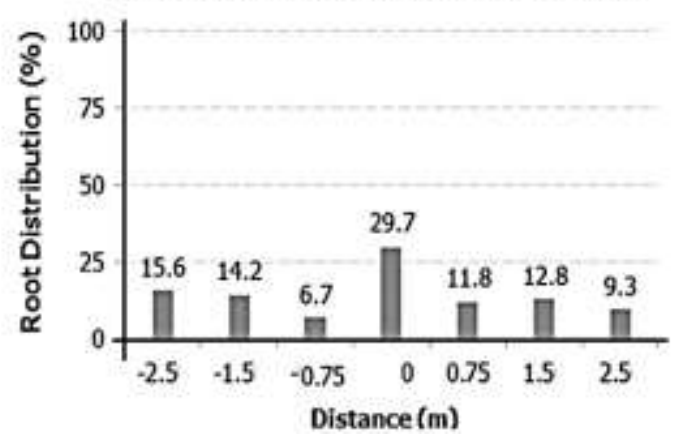

(e) Root distribution with soil depth

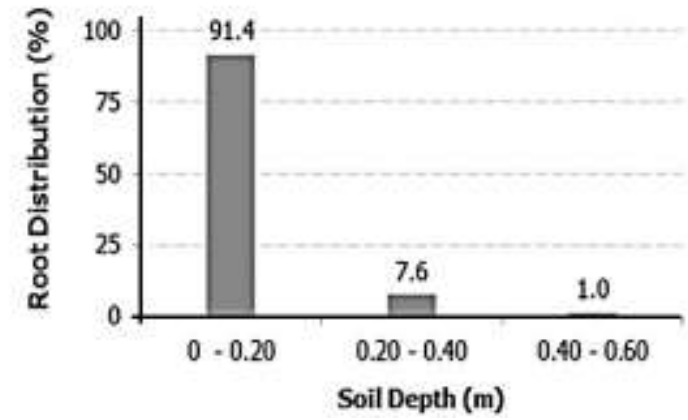

Fig. 8 Root density (kg m-3) within (a) $0-0.2 \mathrm{~m}$, (b) $0.2-0.4 \mathrm{~m}$, (c) $0.4-0.6 \mathrm{~m}$ of the soil profile, and (d) lateral and (e) vertical distribution of total root (\%) in the profile (0 - 0.6 m) of the single-row with kikuyu silvopastoral treatment (SR) at Ukulinga, South Africa. Note that different Y-axis scales are used in a, b and c. 

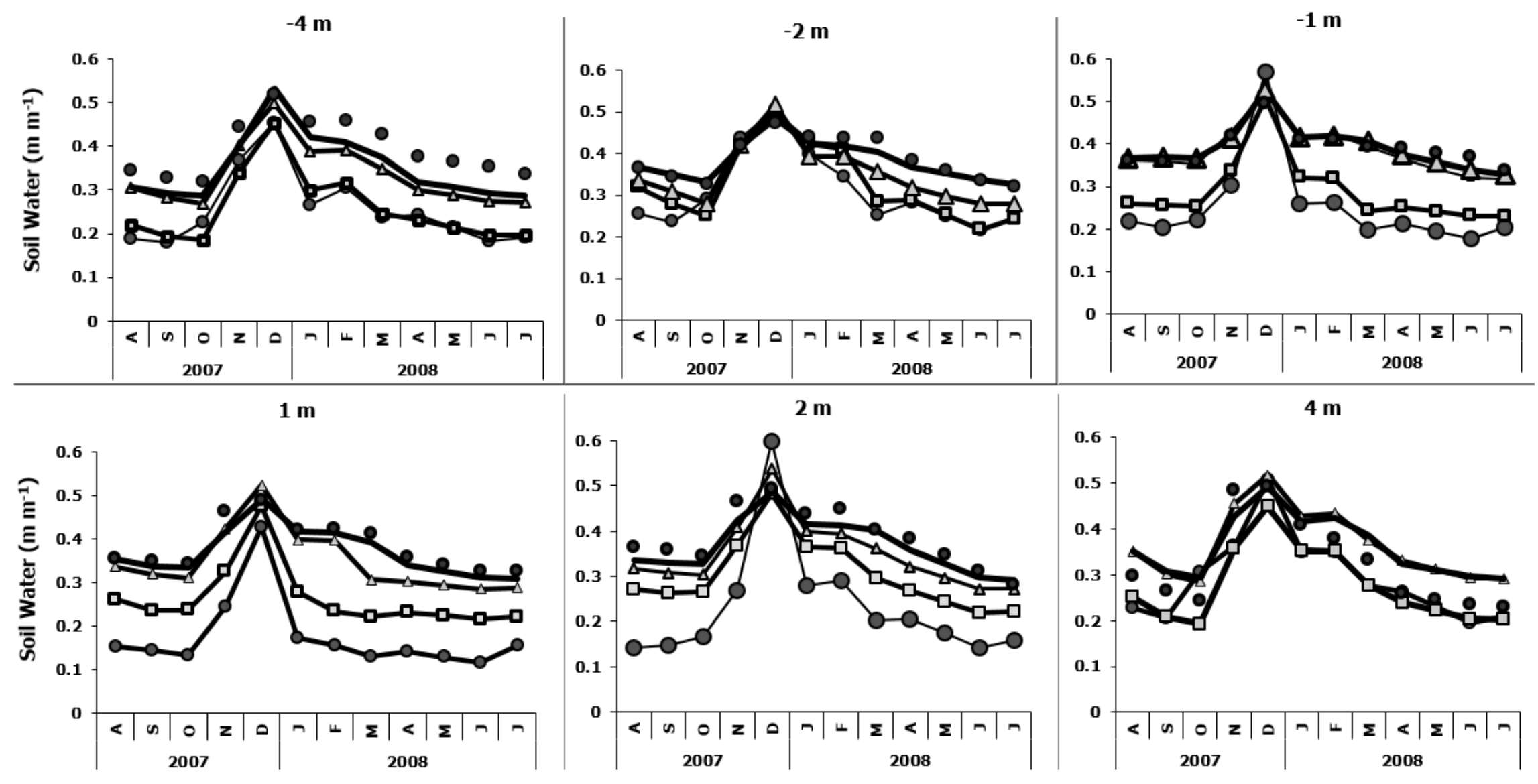
treatments also contributed to ET differences. Ratios of water use to ET of JO and SR trees were not the same. For example, in January, tree water use was $27 \mathrm{~mm}$ (18.3\% of ET) for SR and $52.1 \mathrm{~mm}$ (37\% of ET) for JO, and during February, water uses of SR and JO trees were $25.1 \mathrm{~mm}(49 \%$ of ET) and $47.1 \mathrm{~mm}(84.2 \%$ of ET) respectively.

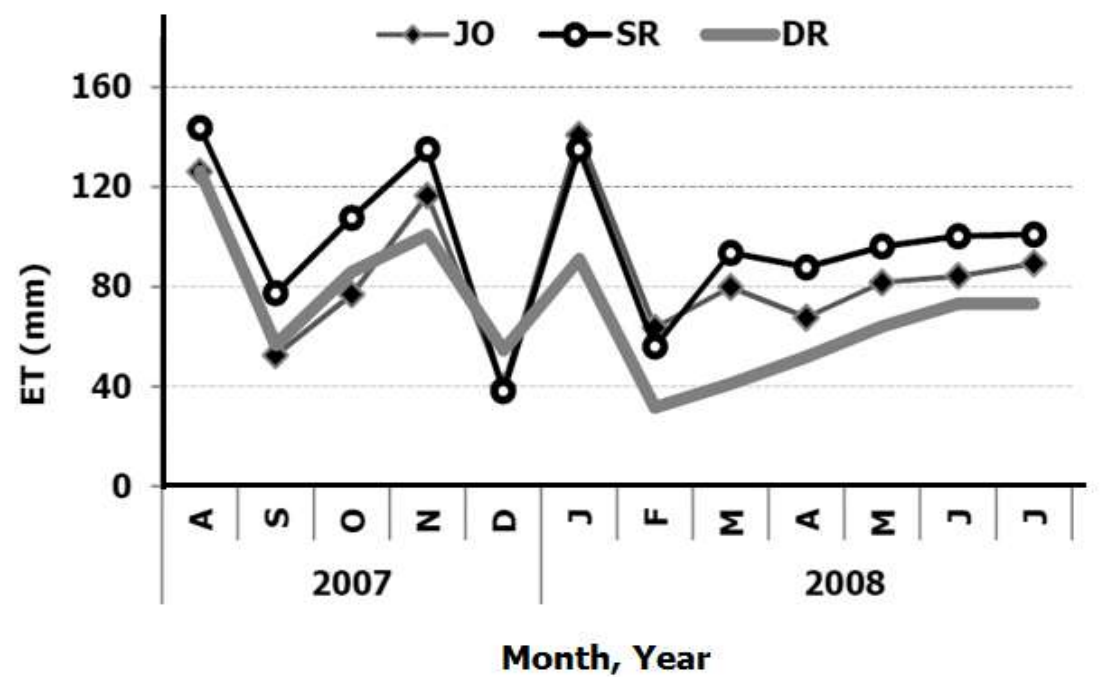

Fig. 10 Monthly evapotranspiration (ET) of the Jatropha-only (JO), single-row with kikuyu (SR) and double-row with kikuyu (DR) treatments at Ukulinga, South Africa from

August 2007 to July 2008. Months are represented by their first letters.

Table 1 Total productivity and ET of the Jatropha-only (JO), the single Jatropha row with kikuyu (SR) and the double Jatropha rows with kikuyu (DR) treatments at Ukulinga, South Africa during the period October 012006 to April 272007

\begin{tabular}{c|cccc}
\hline Treatment & $\begin{array}{c}\text { Tree yield } \\
(\mathbf{t} \text { ha-1) }\end{array}$ & $\begin{array}{c}\text { Tree AG dry mass } \\
(\mathbf{t} \text { ha-1) }\end{array}$ & $\begin{array}{c}\text { Grass yield } \\
(\mathbf{t ~ h a - 1 )}\end{array}$ & $\begin{array}{c}\text { Total ET } \\
(\mathbf{m m})\end{array}$ \\
\hline JO & 0.1 & 3.7 & - & 1019 \\
SR & 0.02 & 2.2 & 8.7 & 1171 \\
DR & 0.02 & 2.3 & 8 & 849 \\
\hline
\end{tabular}

\subsection{Intercrop Productivity}

There were contrasts in the significance of grass yield increases with distance on NE and SW of the treatments. Yields at the same distance on NE and SW were not significantly different (Fig. 11). In SR, the highest grass yield and consistently high ET at $2.5 \mathrm{~m} \mathrm{NE}$ implying grass water use was major ET component. At $0.83 \mathrm{~m}$, yields on NE (2.61 t ha $\left.{ }^{-1}\right)$ and SW $\left(3.03 \mathrm{t} \mathrm{ha}^{-1}\right)$ were not significantly different despite irradiance differences at these positions. Despite higher irradiance at $1.6 \mathrm{~m}$ and $2.5 \mathrm{~m}$ on SW, yield was the highest $\left(7.03 \mathrm{t} \mathrm{ha}^{-1}\right)$ at $2.5 \mathrm{~m}$ NE where water content difference between wet and dry periods was the highest $(\approx 170 . \mathrm{mm})$, strong RGR-SWD correlation $\left(\mathrm{R}^{2}=0.87\right)$ occurred, soil water variations with depth were relatively small (Fig. 7) and ET was the highest. The strongest RGR-SWD correlations at $0.83 \mathrm{~m}$ on NE and SW were indicative of the intensive interspecies competition for water kikuyu experienced. In DR, during 2006-2007, SW had higher grass yield 

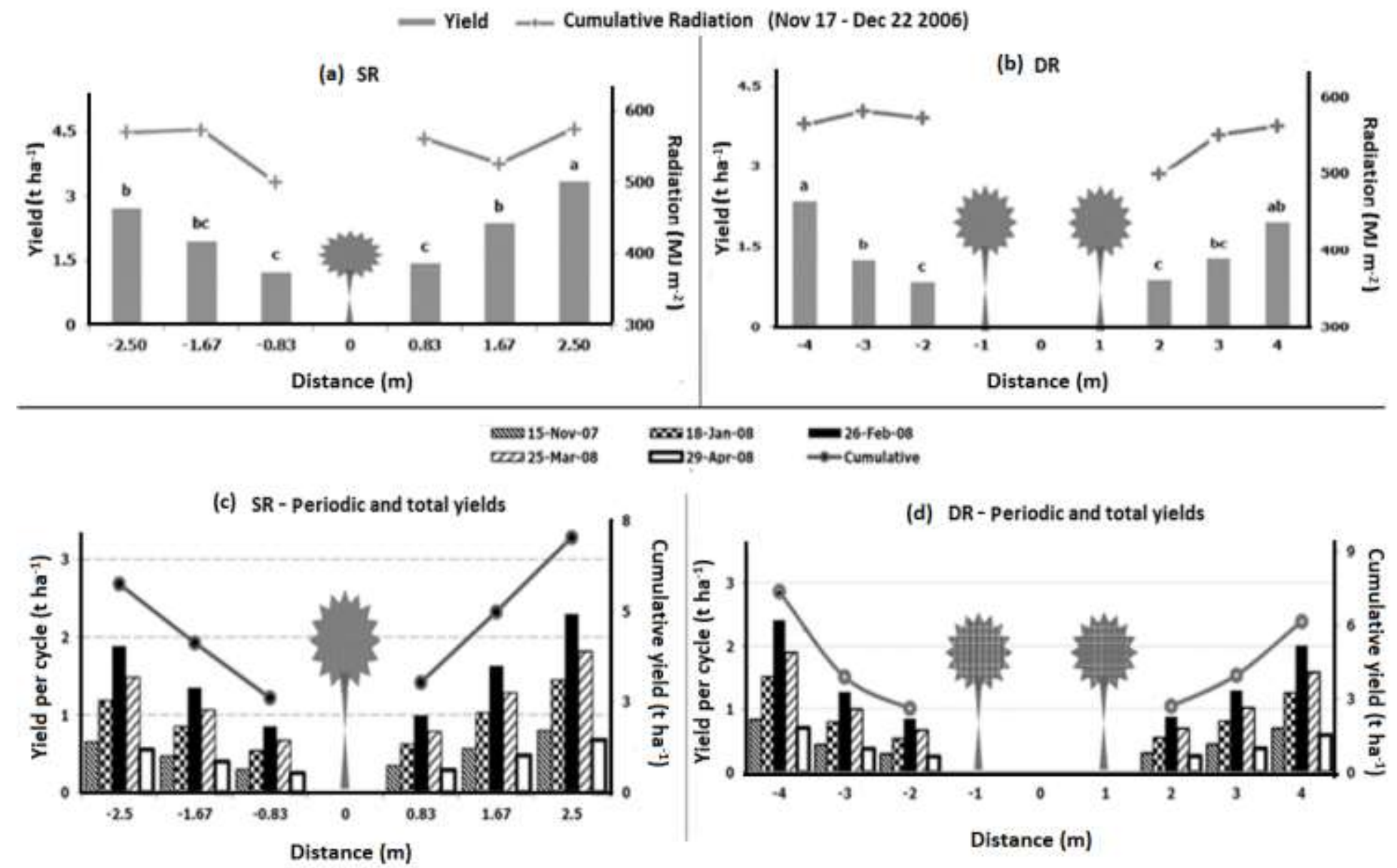
and cumulative irradiance than NE (Fig. 11b, d). High productivity periods (January 18 to February 262008 and February 27 to March 25 2008) coincided with high rainfall, yet wet-period soil water distribution with distance was generally inverse of grass yield. DR had lower yields $\left(8 \mathrm{t} \mathrm{ha}^{-1}\right.$ in $2006-07 ; 4 \mathrm{t} \mathrm{ha}^{-1}$ in 2007-08) than SR (8.7 t $\mathrm{ha}^{-1}$ in 2006-07; $4.3 \mathrm{t} \mathrm{ha}^{-1}$ in 2007-08) due to more extensively developed tree roots in DR, and stronger SWDgrass yield correlation in DR $\left(R^{2}=0.61\right)$ than $S R\left(R^{2}=0.16\right.$ to 0.38$)$. Correlations between kikuyu yield and irradiance were poor (SR: $\mathrm{R}^{2}=0.32$; DR: $\left.\mathrm{R}^{2}<0.1\right)$, and radiation use efficiency (RUE) of kikuyu in SR and DR increased with distance from tree hedgerows (Table 2).

Table 2 Radiation use efficiency (g MJ-1) of kikuyu on the southwestern and the northeastern sides of the single Jatropha row (SR) and the double Jatropha rows (DR) of silvopastoral treatments at Ukulinga, South Africa during November and December 2006

\begin{tabular}{|c|c|c|c|c|c|c|c|}
\hline Treatments & \multicolumn{3}{|c|}{ Southwestern (SW) } & \multicolumn{3}{|c|}{ Northeastern (NE) } & Average \\
\hline SR & $\begin{array}{c}\mathbf{2 . 5} \mathbf{~ m} \\
0.32\end{array}$ & $\begin{array}{c}\mathbf{1 . 6 7} \mathbf{~ m} \\
0.23\end{array}$ & $\begin{array}{c}\mathbf{0 . 8 3} \mathbf{~ m} \\
0.17\end{array}$ & $\begin{array}{c}\mathbf{0 . 8 3} \mathbf{~ m} \\
0.17\end{array}$ & $\begin{array}{c}\mathbf{1 . 6 7} \mathbf{~ m} \\
0.30\end{array}$ & $\begin{array}{c}\mathbf{2 . 5} \mathbf{~ m} \\
0.39\end{array}$ & 0.27 \\
\hline DR & $\begin{array}{l}\mathbf{4} \mathbf{~ m} \\
0.44\end{array}$ & $\begin{array}{c}\mathbf{3 ~ m} \\
0.21\end{array}$ & $\begin{array}{l}\mathbf{2} \mathbf{~ m} \\
0.14\end{array}$ & $\begin{array}{l}\mathbf{2} \mathbf{~ m} \\
0.17\end{array}$ & $\begin{array}{c}\mathbf{3} \mathbf{~ m} \\
0.23\end{array}$ & $\begin{array}{l}\mathbf{4} \mathbf{~ m} \\
0.34\end{array}$ & 0.25 \\
\hline
\end{tabular}

4 DISCUSSION

Weak correlations between grass biomass and irradiance in our study, which occurred despite no nutrient limitation and high rainfall during the particular study period, were in contrast to strong linear correlations $\left(\mathrm{R}^{2}=\right.$ 0.9) reported previously (Sibbald and Sinclair 1990; Knowles et al. 1999; González-Hernández and RozadosLorenzo 2008). The decrease in RUE towards tree rows could be due to the increasing interspecific competition for water being more critical to grass yield than radiation. It could also be due to reduced photosynthetically active radiation reaching the grass resulting from preceding interactions between irradiance and tree canopy (Ong et al. 2015).

Soil water was asymmetrically distributed, and varied with rainfall, depth and among treatments. Unlike in previous studies, which showed reduced soil water content close to trees (Malik and Sharma 1990; Onyewotu et al. 1995; Livesley et al. 2000; Odhiambo et al. 2001), our treatments did not exhibit consistent soil water increase or decreases towards tree hedgerows. Due to the absence of interspecific competition, JO had the biggest trees (Ghezehei et al. 2015) and their roots did not have to explore the soil profile for water. SR and DR trees had comparable RGRs, yet DR had lower grass yield and its trees explored soil profile more comprehensively, which could suggest more intensive interspecific and intraspecific competition. Eastham and Rose (1990) found that at high tree density, tree-tree competition resulted in higher tree root production and 
more extensive exploration of the soil profile. This could be the case in DR where trees were more clustered than SR although plot-level tree density was the same for all treatments.

Tree root distribution can be used as an indicator of competition potential of trees, and high fine root concentrations of trees within crop root zone has been observed in previous studies involving fast growing trees (Jonsson et al. 1988; Daniel et al. 1991; Van Noordwijk et al. 2015). Previous studies have shown that the concentration of fine tree roots decreases with distance from trees (Eastham and Rose 1990; Van Noordwikk et al. 2015; Livesley et al. 2000). Our inferences based on RGR-SWD correlations did not agree with these studies although total (woody and fine roots) root density in SR generally decreased with distance from the tree hedgerow. In our combination treatments, tree and grass roots overlapped greatly due to shallow tree roots and limited soil depth $(0.6 \mathrm{~m})$ resulting in severe competition for water. There was no clear relationship between grass and root distribution.

In the current study, tree arrangement without changing density had no consistent effects on tree growth and yield (Ghezehei et al. 2015), and tree allometric relationships were not affected by interspecific competition or tree arrangements (Ghezehei et al. 2009). High grass growth coincided with high rainfall periods, and grass yield consistently increased with increasing distance from tree rows, which was in agreement with previous studies (González-Hernández and Rozados-Lorenzo 2008; Huth et al. 2010). Jatropha and kikuyu are mostly dormant during extended dry periods and active during the rest of the year leaving no room for temporal complementarity between them. Ghezehei et al. (2015) reported significant stem growth in the treatments of the current study, which was in agreement with a study by Huth et al. (2010) that tree roots can explore intercropping zone for water before and during growing seasons. Taking into consideration total productivity (trees and grass) and total ET (Table 1), DR in our study was better tree arrangement than SR.

\section{CONCLUSIONS}

We examined distribution of radiation and soil water and growth of intercrops in a silvopastoral system with different tree arrangements but the same tree density in order to understand the extent of T-C interactions of HI. Our hypothesis about linear correlations between radiation and plant growth when other resources are not limited was rejected while the hypothesis that water availability is more critical to $\mathrm{T}-\mathrm{C}$ interactions than radiation in semi-arid climate was accepted. Finally, the hypothesis that it is possible to manipulate tree arrangement without changing density in order to optimize radiation and water distribution and intercrop growth in $\mathrm{HI}$ was also accepted. Our findings add insight to resource use and T-C interactions in HI, and contribute to 
the implementation and management of efficiently designed HI, and more design options should be explored to ascertain the full potential of these findings.

\section{Acknowledgements}

The authors would like to thank Water Research Commission (WRC) of South Africa for funding the project (K5/1480/1/12), CSIR-Natural Resource \& Environment for collaborating on this research, and Mr Lelethu Sinuka and Dr. Michael Abraha for their assistance during data collection.

\section{REFERENCES}

Balandier P, DE Montard FX, Curt T (2008) Root competition for water between trees and grass in a silvopastoral plot of 10 year old Prunus avium. In: Batish DR, Kohli RK, Jose S, Singh HP (eds.) Ecological basis of agroforestry, CRC Press, Boca Raton, pp 253-270.

Bayala J, Wallace JS (2015) The water balance of mixed tree-crop systems. In: Ong CK, Black C, Wilson J (eds.) Tree-crop interactions, $2^{\text {nd }}$ edition: Agroforestry in a changing climate, CAB International, Wallingford, pp 146-190.

Berlyn GP, Cho J (2000) Light, moisture and nutrient use by plants. In: Ashton MS, Montagnini F (eds.) The silvicultural basis for agroforestry systems, CRC Press, Boca Raton, pp 9-39.

Black CR, Radhawa D, Ong CK (2015) Principles of resource capture and use of light and water. In: Ong CK, Black C, Wilson J (eds.) Tree-crop Interactions, $2^{\text {nd }}$ edition: Agroforestry in a changing climate, CAB International, Wallingford, pp 57-120.

Camp KG (1997) The Bioresource Groups of KwaZulu-Natal. Department of Agriculture, Cedara Report No. N/A/97/6. KZN South Africa.

Daniel JN, Ong CK, Kumar MS (1991) Growth and resource utilization of perennial pigeonpea (Cajanus cajan (L) Millsp) at the tree-crop interface. Agroforest Syst 12:83 - 98.

Eastham J, Rose CW (1990) Tree/pasture interactions at a range of tree densities in an agroforestry experiment. I. Rooting patterns. Aus J Agr Res 41:683-695.

Everson CS, Ghezehei SB, Everson TM, Annandale J (2012) Agroforestry systems for improved productivity through the efficient use of water. Water Research Commission Report No. 1480/1/12, Pretoria, South Africa.

Ghezehei SB, Annandale JG, Everson CS (2009) Shoot allometry of Jatropha curcas. South Forests 71(4):279-286. 
Ghezehei SB, Everson CS, Annandale JG (2015) Can productivity and post-pruning growth of Jatropha curcas in silvopastoral systems be regulated by manipulating tree spacing/arrangement without changing tree density? Biomass Bioenerg 74:233-243.

González-Hernández MP, Rozados-Lorenzo MJ (2008) Pasture production and tree growth in agroforestry system of Northwest Spain. In: Batish DR, Kohli RK Jose S, Singh HP (eds.) Ecological Basis of Agroforestry, CRC Press, Boca Raton, pp 361-373

Huth NI, Robertson MJ, Poulton PL (2010) Regional differences in tree-crop competition due to soil, climate and management. Crop Pasture Sci 61:763-770.

Huxley P (1999) Tropical agroforestry. Blackwell Science Ltd, London.

Jonsson K, Fidgeland L, Maghambe JA, Hogberg P (1988) The vertical distribution of fine roots of five tree species and maize in Morogor, Tanzania. Agroforest Syst 6:63-69.

Knowles RL, Horvath GC, Carter MA, Hawke MF (1999) Developing a canopy closure model to predict overstorey/understorey relationships in Pinus radiate silvopastoral systems. Agroforest Syst 43:109119.

Livesley SJ, Gregory PJ; Buresh RJ (2000) Competition in tree row agroforestry systems. 1. Distribution and dynamics of fine root length and biomass. Plant Soil 227:149-161.

Malik RS, Sharma SK (1990) Moisture extraction and crop yield as a function of distance from a row of Eucalyptus tereticornis. Agroforest Syst 12:187-195.

Odhiambo HO, Ong CK, Deans JD, Wilson Jkhan AAH, Sprent JI (2001) Roots, soil water and crop yield: tree crop interactions in a semi-arid agroforestry system in Kenya. Plant Soil 235:331-233.

Ong CK, Kho RM (2015) A framework for quantifying the various effects of tree-crop interactions. In: Ong CK, Black C, Wilson J (eds.) Tree-crop interactions, $2^{\text {nd }}$ edition: Agroforestry in a changing climate, CAB International, Wallingford, pp 1-23.

Black CR, D Randhawa, Ong CK (2015) Principles of resource capture and utilization of light and water. In: Ong CK, Black C, Wilson J (eds.) Tree-crop interactions, $2^{\text {nd }}$ edition: Agroforestry in a changing climate, CAB International, Wallingford, pp 57-118.

Ong CK, Black CR, Wallace JS, Khan AAH, Lott JE, Jackson NA, Howard SB, Smith DM (2000) Productivity, microclimate and water use in Grevillea Robusta-based agroforestry systems on hillslopes in semi-arid Kenya agriculture. Agr Ecosyst Environ 80:121-141. 
Ong CK, Black CR, Wilson J, Muthuri C, Bayala J, Jackson NA (2014) Agroforestry: Hydrological impacts. In: Van Alfen N, (ed.) Encyclopedia of agriculture and food systems, Vol. 1, Elsevier, San Diego, pp 244-252.

Ong CK, Wilson J, Deans JD, Mulayta J, Raussen T, Wajja-Musukwe N (2002) Tree-crop interactions: manipulation of water use and root function. Agr Water Manage 53:171-186.

Onyewotu LOZ, Stigter CJ (1995) Eucalyptus - its reputation and its roots: millet and a Eucalyptus shelterbelt in Northern Nigeria. Agroforst Today 7:6-8.

SAS software, Version 9.01 of the SAS System for Windows. Copyright @ 2002 by SAS Institute Inc., Cary, NC, USA.

Sibbald AR, Sinclair FL (1990) A review of agroforestry research in progress in the UK. Agroforest Abstracts 3(4):149-164.

PCTDR software, TDR Graphing PC Software, Version 2.07; Copyright @ 1997, 2001, by Campbell Scientific, Inc., Logan, UT, USA.

Van Noordwijk M, Lawson G, Hairiah K Wilson J (2015) Root distribution of trees and crops: competition and/or complementarity. In: Ong CK, Black C, Wilson J (eds.) Tree-crop interactions, $2^{\text {nd }}$ edition: Agroforestry in a changing climate, CAB International, Wallingford, pp 221-257. 